\title{
Hydroid epifaunal communities in Arctic coastal waters (Svalbard): effects of substrate characteristics
}

\author{
Marta Ronowicz • Maria Włodarska-Kowalczuk • \\ Piotr Kukliński
}

Received: 28 July 2012/Revised: 4 January 2013/Accepted: 17 January 2013/Published online: 13 February 2013

(C) The Author(s) 2013. This article is published with open access at Springerlink.com

\begin{abstract}
The knowledge of cryptic epifaunal groups in the Arctic is far from complete mostly due to logistic difficulties. Only recently, advances in sample collection using SCUBA diving techniques have enabled to explore delicate hydroid fauna from shallow waters. This study is the first attempt to examine the relationship between substrate property (such as size of rock, morphological characteristics of algal or bryozoan host) and hydroid community composition and diversity in the Arctic. Samples of substrates for hydroid attachment including rocks, algae, bryozoans and other hydrozoans were collected around the Svalbard. Examination revealed no substratespecific species. The substrate property did not have a strong influence on hydroid community. Both species composition and richness were not related to colonized rock surface area and to morphological characteristic of algal host. Therefore, results indicate the opportunistic nature of hydroid fauna in terms of substrate preference. However, the presence or absence of hydroids depended on the surface area of rocky substrate. Hydroids were more often present on rocks of larger surface area. Erect hydroids and bryozoans were important attachment surface for stolonal hydroids.
\end{abstract}

Keywords Hydrozoa - Biodiversity - Distribution · Occurrence · Habitat - Epifauna - Spitsbergen

\footnotetext{
M. Ronowicz $(\bowtie) \cdot$ M. Włodarska-Kowalczuk · P. Kukliński Institute of Oceanology, Polish Academy of Sciences, ul. Powstancow Warszawy 55, 81-712 Sopot, Poland e-mail: martigor1@o2.pl

P. Kukliński

Natural History Museum, Cromwell Road, SW7 5BD London, UK
}

\section{Introduction}

Hydroids (sessile stage of Hydrozoa) may grow on a variety of hard substrates (rocks, plastics, glass, wood) as well as on living or dead organisms (Gili and Hughes 1995). They are known as common components of fouling communities. Owing to their rapid growth rates and opportunistic nature, hydroids are successful pioneer organisms that are often among the first colonists of unoccupied surface (Boero 1984; Hughes et al. 1991). In frequently disturbed environments, they are capable of establishing the first stage of epibiotic succession (Dean and Hurd 1980; Orlov 1997). Their dominance is usually only temporary and limited to the first phases of succession (Boero 1984). In next stages of succession, they are frequently replaced by superior competitors such as algae, ascidians, sponges, barnacles, bryozoans and polychaetes (Boero 1984; Barnes and Kuklinki 2004). However, there is also an example indicating a different settlement strategy of hydroid. Experimental panel assemblage dominated by Hydractinia echinata (Fleming 1828) was very persistent and did not change throughout several recruitment seasons (Sutherland 1981). This means that this species is long lived and resistant to larval recruitment of other species (Sutherland and Karlson 1977; Sutherland 1981).

Both ecological papers and taxonomical revisions frequently report the type of substrate to which hydroids are attached (Naumov 1969; Zamponi et al. 1998; Schuchert 2001; Genzano et al. 2009). However, detailed analyses of the relationships between substrate characteristics and hydroid diversity or community structure in the Arctic are lacking. Some efforts have been recently undertaken to examine the substrate type and its hydrozoan fouling assemblage in the Arctic (Ronowicz et al. 2008, 2013; Voronkov et al. 2010). In other regions, this topic is much 
better recognized. A rich literature is dedicated to examine both the epiphytic (Coma et al. 1992; Watson 1992; Faucci and Boero 2000) and the epizootic (Boero and Hewitt 1992; Cerrano et al. 2001; Puce et al. 2008) interactions of hydroids with their host organisms. Rocky substrate was much less investigated. There are a few published surveys in which rocks and cobbles are mentioned to serve as substrates for hydroid settlements, but with no reference to substrate characteristics (e.g., Nishihira 1965; Genzano and Rodriguez 1998; Henry et al. 2008).

In this paper, we describe patterns of distribution and diversity of hydroids colonizing four substrates: rocks, algae, Bryozoa and Hydrozoa in the Arctic waters of Svalbard archipelago. We explore the effects of substrate characteristics on hydroid community composition and diversity.

\section{Study area}

The sampling area was located around the Svalbard archipelago (Fig. 1), a group of islands between $74^{\circ}-81^{\circ} \mathrm{N}$ and $10^{\circ}-35^{\circ} \mathrm{E}$. The largest island is Spitsbergen. The archipelago features an Arctic climate, with significantly higher temperatures on the west coast than on the east one. This is caused by the influence of warm Atlantic waters flowing northward along the west coast with the West Spitsbergen Current $\left(T>2{ }^{\circ} \mathrm{C}, S>34.7\right.$ PSU) (Svendsen et al. 2002). Cold water masses from the north $\left(T<0{ }^{\circ} \mathrm{C}\right.$, $S=34.3-34.8$ PSU) flows southward as the East Spitsbergen Current and mostly affects the eastern part of the
Svalbard Archipelago (Loeng 1991). The southern extension of this cold water masses, the Sørkapp Current, turns to the north beyond South Cape, and then, runs north parallel to the West Spitsbergen Current.

The most characteristic attributes of the Svalbard landscape are glaciers covering over $60 \%$ of its land mass and deep and narrow fjords of glacial origin indenting main islands. The fjords are filled with soft sediment delivered with glacier outflows. Hard bottom prevails in shallow areas exposed to strong currents (Gulliksen and Svensen 2004).

\section{Methods}

Material used in this study comes from several scientific expeditions to Svalbard aboard the r/v Oceania (July 2002, 2004, 2005, 2006, 2007), the r/v Jan Mayen (September 2001), and the r/v Lance (October 2007), as well as during expeditions based at the Polish Polar Station in Hornsund in July 2003 and July 2006 (Table 1). Supplementary samples, provided by Akvaplan-niva, were collected off the east coast of Svalbard in 1996. The majority of the sampling stations were located off the west coast of Spitsbergen, especially in Hornsund fjord. Altogether 557 samples were collected from around the entire archipelago with use of different types of gears (SCUBA divers, dredging, van Veen grab with a catch area of $0.1 \mathrm{~m}^{2}$ ), from intertidal down to $329 \mathrm{~m}$ depth. The samples were fixed in a $4 \%$ buffered formalin solution. Substrates with attached fauna were carefully examined in the laboratory. Hydroid
Fig. 1 Svalbard archipelago with sampling sites marked with circles

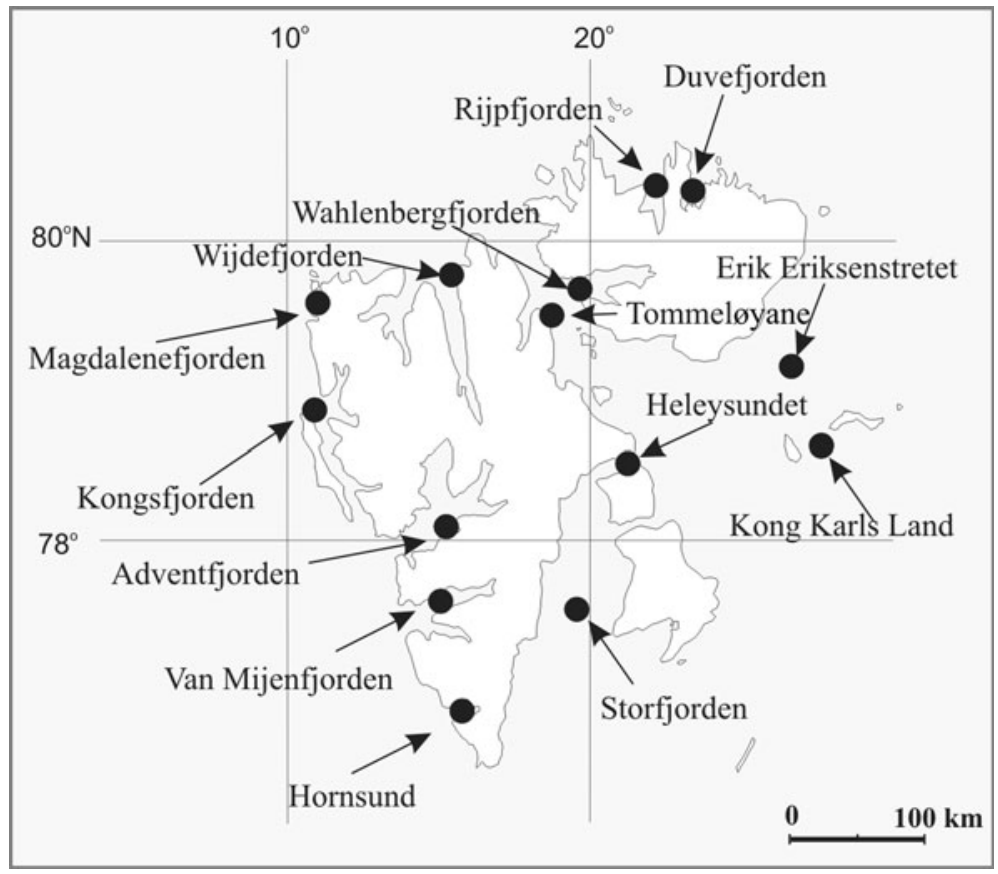


Table 1 Station sampling information

\begin{tabular}{|c|c|c|c|c|c|}
\hline Station & Coordinates & Depth (m) & Years & Type of gear & Number of samples \\
\hline Adventfjorden & $78^{\circ} 15^{\prime} 15^{\prime \prime} ; 15^{\circ} 29^{\prime} 47^{\prime \prime}$ & $20-80$ & 2004 & Van Veen grab & 12 \\
\hline Duvefjorden & $80^{\circ} 08^{\prime} 32^{\prime \prime} ; 23^{\circ} 07^{\prime} 32^{\prime \prime}$ & $119-183$ & 2001 & Van Veen grab & 3 \\
\hline Erik Eriksenstretet & - & 219 & 1996 & Van Veen grab & 1 \\
\hline Heleysundet & $78^{\circ} 25^{\prime} 50^{\prime \prime} ; 21^{\circ} 18^{\prime} 46^{\prime \prime}$ & 13 & 2001 & Diving-frame & 1 \\
\hline \multirow[t]{5}{*}{ Hornsund } & $76^{\circ} 59^{\prime} 46^{\prime \prime} ; 15^{\circ} 33^{\prime} 27^{\prime \prime}$ & $5-10$ & 2003 & Diving-algae & 340 \\
\hline & $76^{\circ} 55^{\prime} 13^{\prime \prime} ; 15^{\circ} 33^{\prime} 06^{\prime \prime}$ & $5-26$ & 2003 & Diving-qualitative & 73 \\
\hline & $77^{\circ} 01^{\prime} 16^{\prime \prime} ; 16^{\circ} 05^{\prime} 50^{\prime \prime}$ & $0-20$ & 2006 & Diving-frame & 41 \\
\hline & $76^{\circ} 35^{\prime} 18^{\prime \prime} ; 16^{\circ} 07^{\prime} 20^{\prime \prime}$ & $79-147$ & 2002 & Dredge & 6 \\
\hline & $76^{\circ} 55^{\prime} 17^{\prime \prime} ; 15^{\circ} 33^{\prime} 57^{\prime \prime}$ & $100-210$ & 2005 & Van Veen grab & 48 \\
\hline Kong Karls Land & - & 117 & 1996 & Van Veen grab & 3 \\
\hline \multirow[t]{3}{*}{ Kongsfjorden } & $78^{\circ} 35^{\prime} 02^{\prime \prime} ; 11^{\circ} 35^{\prime} 02^{\prime \prime}$ & $10-20$ & 2001 & Diving-qualitative & 4 \\
\hline & $78^{\circ} 35^{\prime} ; 10^{\circ} 35^{\prime}$ & $103-329$ & 2007 & Triangle sledge & 3 \\
\hline & $79^{\circ} 00^{\prime} 28^{\prime \prime} ; 10^{\circ} 00^{\prime} 28^{\prime \prime}$ & $145-320$ & 2004 & Van Veen grab & 5 \\
\hline Magdalenefjorden & $79^{\circ} 33^{\prime} 59^{\prime \prime} ; 11^{\circ} 05^{\prime} 07^{\prime \prime}$ & $51-100$ & 2007 & Van Veen grab & 2 \\
\hline \multirow[t]{2}{*}{ Rijpfjorden } & - & $5-30$ & 2007 & Diving-qualitative & 2 \\
\hline & $80^{\circ} 27^{\prime} ; 22^{\circ} 34^{\prime}$ & 140 & 2007 & Triangle sledge & 1 \\
\hline Storfjorden & - & 109 & 1996 & Van Veen grab & 3 \\
\hline Tommeløyane & $79^{\circ} 19^{\prime} 46^{\prime \prime} ; 18^{\circ} 28^{\prime} 01^{\prime \prime}$ & 23 & 2001 & Diving-frame & 2 \\
\hline Wahlenbergfjorden & $79^{\circ} 23^{\prime} 41^{\prime \prime} ; 19^{\circ} 29^{\prime} 49^{\prime \prime}$ & $10-30$ & 2001 & Diving-qualitative & 1 \\
\hline Wijdefjorden & $71^{\circ} 04^{\prime} 32^{\prime \prime} ; 16^{\circ} 02^{\prime} 41^{\prime \prime}$ & $10-20$ & 2001 & Diving-qualitative & 1 \\
\hline Van Mijenfjorden & $77^{\circ} 31^{\prime} 14^{\prime \prime} ; 16^{\circ} 22^{\prime} 14^{\prime \prime}$ & 25-107 & 2007 & Van Veen grab & 5 \\
\hline
\end{tabular}

species were identified to the lowest level possible under a stereomicroscope and microscope whenever needed. Then, each substrate was treated as a separate sample, for example, each rock collected in the whole studied area was treated as a separate sample in the analysis of hydroid fauna associated with rocks. The species occurrence on substrate was noted, but the numbers of colonies were not assessed. It is often impossible with modular and clonal organisms to determine the size and extent of particular colonies throughout epifaunal communities (Gili and Hughes 1995). We use a term species record to articulate the species' presence and number of records to count the species occurrences on particular substrate.

\section{Rocks}

Rock samples were separated a priori according to depth of collection into shallow and deep with the boundary at $40 \mathrm{~m}$ depth. Such division was supported by the distribution of another colonial epifaunal taxon-Bryozoa in Arctic fjords (Kukliński et al. 2005) and in western Norway (Ryland 1963). The rationale behind this division was substrate and light limitation below $40 \mathrm{~m}$ depth, larval response to light during dispersal, and temperature and salinity fluctuations in the upper water column.

The surface area of each rock was measured using a plastic net marked with a $\mathrm{cm}^{2}$ grid. Additionally, the diameter of each rock was measured so they could be sorted by size category. The classification followed the Wentworth scale (Wentworth 1922) in which the size of particles determines the rock class name: fine gravel (4-8 mm), medium gravel $(8-16 \mathrm{~mm})$, coarse gravel (16-32 mm), very coarse gravel $(32-64 \mathrm{~mm})$ and cobble (64-245 mm). The correlations between the number of species per sample and rock size and the number of species per sample and depth were calculated with use of Spearman's rank correlation coefficient. Logistic regression was used to predict the probability of hydroid presence or absence on rocks. The model describes the relationship between independent variables (depth classes: shallow $\leq 40 \mathrm{~m}$ and deep $>40 \mathrm{~m}$ and rock surface area) to the binary dependent variable (presence or absence of hydroids). Rosenbrock and quasi-Newton methods of estimation were performed while building the logistic models. The $t$ statistic was used to test the significance of individual logistic regression coefficients for each independent variable (i.e., to test the null hypothesis in logistic regression that a particular logit (effect) coefficient was zero). The Wald test was used to check whether the model was improved significantly after entering each variable (STATISTICA v. 6, Statsoft). Pearson's chi-square test of independence was used to test whether hydroid occurrence on rocks differed between different rock size classes and in different depth classes. 
Relationships between species distributions and depth and rock size were examined using the BIO-ENV procedure. The similarity matrices were based on Bray-Curtis index for biotic species data and on Euclidean distance for environmental variables (analysis performed with use of PRIMER package v. 6, Clarke and Warwick 2001).

\section{Algae}

The collected algae were divided into groups of species related to their taxonomic affinities or morphological characteristics. Three groups of species representing divisions were identified: Chlorophyta, Phaeophyta and Rhodophyta. The algal species were classified according to morphological types (modified after Lippert et al. 2001) as follows: (1) foliose to membranous-Phycodrys rubens, Alaria esculenta, Callophyllis cristata; (2) filamentousOdonthalia dentata, Acrosiphonia sonderi, Chorda tomentosa, Dumontia contorta, Dictiosiphon foeniculaceus, Desmarestia aculeata, Sphacelaria arctica; and (3) leathery-Saccharina latissima, Laminaria digitata, Laminaria solidungula, Laminaria hyperborea, Fucus distichus.

One-way ANOSIM pair-wise statistic was used to test dissimilarities between hydroid assemblages colonizing Phaeophyta and Rhodophyta division and between different algal morphological types (PRIMER package v. 6, Clarke and Warwick 2001). Non-metric multidimensional scaling (nMDS) of Bray-Curtis similarities of hydroid species occurrence on algae was conducted for all samples (PRIMER package v. 6, Clarke and Warwick 2001).

\section{Bryozoa and Hydrozoa}

All hydroid-bryozoan and hydroid-hydroid associations which are defined as the number of hydroid records on bryozoan or other hydroid host were noted.

The morphological forms of bryozoan and hydrozoan host species were recorded. Bryozoans were classified as erect (upright shoots) or encrusting (flat, runner-like colonies), hydroids - as erect (upright shoots) or stolonal (horizontal, runner-like colonies). One-way analyses of similarities ANOSIM were used to test dissimilarities in hydroid composition among different bryozoan host species and among different hydrozoan host species (PRIMER package v. 6, Clarke and Warwick 2001). The frequency of hydroid occurrence on particular substrate was calculated as the percentage of substrate samples colonized by species in the total number of colonized substrate. The mean sample species richness on the colonized substrates was determined. The nonparametric Kruskal-Wallis test was used to check for significant differences in the species richness among: (1) rock samples from different depth zones and of different size classes, (2) algal samples of
Phaeophyta and Rhodophyta (Chlorophyta was excluded from the analysis because of the small number of records) and representing different algal morphological types (STATISTICA v.6, Statsoft).

\section{Results}

Several substrates collected during present study were colonized by hydroids: rocks, 14 taxa of algae, other hydroids, bryozoans, bivalve shells, gastropods, Balanus sp., shells of Buccinum sp. inhabited by hermit crabs, crab exoskeletons, polychaete tubes, ascidians, poriferans, soft corals and foraminiferans. For the detailed analyses, we have chosen the most frequently colonized substrate types, that is, rocks, algae, bryozoans and other hydroids. As many as $34 \%$ of algae and $31 \%$ of rocks were colonized by hydroids. Bryozoa and Hydrozoa were colonized less frequently ( 9 and $3 \%$ of substrate samples, respectively). In total, 43 species of hydroids were noted on selected substrates in Svalbard waters (Table 2). Fifteen species inhabited only one type of substrate but all of them were rare.

\section{Rocks}

There were 384 rock samples examined in the study area. Thirty-one percent of rocks were colonized by hydroids. There were 25 species recorded on this type of substrate and five of them were present exclusively on rocky substrates (Abietinaria pulchra, Eudendrium cf. rameum, Lafoeina maxima, Sertularia schmidti, Sarsia loveni). However, their total number of records was very low $(<10)$. The mean rock sample species richness was 1.5 $( \pm 0.7 \mathrm{SD})$ and varied between 1 and 6 species per rock.

The samples included rocks of surface area ranging from 0.5 to $836 \mathrm{~cm}^{2}$ and were collected at depths from 5 to $329 \mathrm{~m}$. The frequency of occurrence of hydroids on rocky substrate was higher in shallow samples $(\leq 40 \mathrm{~m})$ and reached $41 \%$ comparing to $19 \%$ in samples collected at depths $>40 \mathrm{~m}$. Differences between the two depth zones were significant as was shown by $\chi^{2}$ test statistic (test $\chi^{2}=20.45, p<0.001$ ). The occurrence of hydroids varied significantly between different rock size classes (test $\chi^{2}=35.5, p<0.001$ ) and increased with the increasing rock size.

The logistic regression model was significant (test $\left.\chi^{2}=47.69, p<0.001\right)$. Both surface area and depth class of studied rocks had a significant influence on hydroids presence ( $p<0.05$ for both factors). Hydroids were recorded more often in shallow waters (Estimate value of logistic regression $=-1.281$ ) and on rocks of larger surface area (Estimate value of logistic regression $=0.005$ ). The depth was much more important than surface area in shaping the hydroids' occurrence on rocky substrates. 
Table 2 Hydroid occurrence on different substrate types

\begin{tabular}{|c|c|c|c|c|}
\hline Species & Rocks & Algae & Bryozoa & Hydrozoa \\
\hline \multicolumn{5}{|l|}{ Leptothecata } \\
\hline \multicolumn{5}{|l|}{ Campanulariidae } \\
\hline Campanularia volubilis (Linnaeus, 1758) & + & + & + & + \\
\hline Gonothyraea loveni (Allman, 1859) & + & + & + & + \\
\hline Obelia longissima (Pallas, 1766) & + & + & + & + \\
\hline Orthopyxis integra (MacGillivray, 1842) & + & + & + & + \\
\hline Rhizocaulus verticillatus (Linnaeus, 1758) & + & & + & \\
\hline \multicolumn{5}{|l|}{ Campanulinidae } \\
\hline Calycella syringa (Linnaeus, 1758) & + & + & + & + \\
\hline Campanulina pumila (G.O. Sars, 1874) & + & + & + & \\
\hline Cuspidella procumbens (Kramp, 1911) & + & + & + & + \\
\hline Cuspidella sp. & + & + & + & \\
\hline Lafoeina maxima (Levinsen, 1893) & + & & & \\
\hline Opercularella lacerata (Johnston, 1847) & + & + & & \\
\hline \multicolumn{5}{|l|}{ Haleciidae } \\
\hline Halecium arcticum (Ronowicz \& Schuchert, 2007) & + & + & + & + \\
\hline Halecium curvicaule (Lorenz, 1886) & + & + & + & + \\
\hline Halecium mirabile (Schydlowsky, 1902) & + & + & + & + \\
\hline Halecium muricatum (Ellis \& Solander, 1786) & & + & + & \\
\hline Halecium cf. speciosum (Nutting, 1901) & & + & & \\
\hline Halecium textum (Kramp, 1911) & & + & & \\
\hline \multicolumn{5}{|l|}{ Lafoeidae } \\
\hline Filellum serpens (Hassall, 1848) & & + & + & \\
\hline Lafoea dumosa (Fleming, 1820) & + & + & + & + \\
\hline \multicolumn{5}{|l|}{ Sertulariidae } \\
\hline Abietinaria pulchra (Nutting, 1904) & + & & & \\
\hline Sertularella polyzonias(Linnaeus, 1758) & & & + & \\
\hline Sertularella rugosa (Linnaeus, 1758) & & + & + & \\
\hline Sertularella tenella (Alder, 1856) & & + & & + \\
\hline Sertularia argentea (Linnaeus, 1758) & + & + & & \\
\hline Sertularia schmidti (Kudelin, 1914) & + & & & \\
\hline Symplectoscyphus tricuspidatus (Alder, 1856) & + & + & + & + \\
\hline \multicolumn{5}{|l|}{ Tiarannidae } \\
\hline Stegopoma plicatile (M. Sars, 1863) & + & & + & + \\
\hline \multicolumn{5}{|l|}{ Anthoathecata } \\
\hline \multicolumn{5}{|l|}{ Bougainvilliidae } \\
\hline Bougainvillia cf. superciliaris (L. Agassiz, 1849) & + & + & + & + \\
\hline Rhizorhagium roseum (Sars, 1874) & + & & + & + \\
\hline \multicolumn{5}{|l|}{ Eudendriidae } \\
\hline Eudendrium annulatum (Norman, 1864) & + & + & & \\
\hline Eudendrium arbuscula (Wright, 1859) & & + & & \\
\hline Eudendrium cf. capillare (Alder, 1856) & + & + & & \\
\hline Eudendrium cf. rameum (Pallas, 1766) & + & & & \\
\hline Eudendrium unispirum (Schuchert, 2008) & & & + & \\
\hline Eudendrium sp. 1 & & & + & \\
\hline \multicolumn{5}{|l|}{ Corynidae } \\
\hline Coryne sp. & & + & & + \\
\hline Sarsia loveni (M. Sars, 1846) & + & & & \\
\hline Sarsia sp. & + & + & & \\
\hline \multicolumn{5}{|l|}{ Hydractiniidae } \\
\hline Clava multicornis (Forskal, 1775) & & + & & \\
\hline Hydractinia cf. monoon (Hirohito, 1988) & & + & & \\
\hline Hydractinia serrata (Kramp, 1943) & & & & + \\
\hline \multicolumn{5}{|l|}{ Oceaniidae } \\
\hline Similomerona nematophora (Antsulevich, 1986) & & + & + & \\
\hline
\end{tabular}




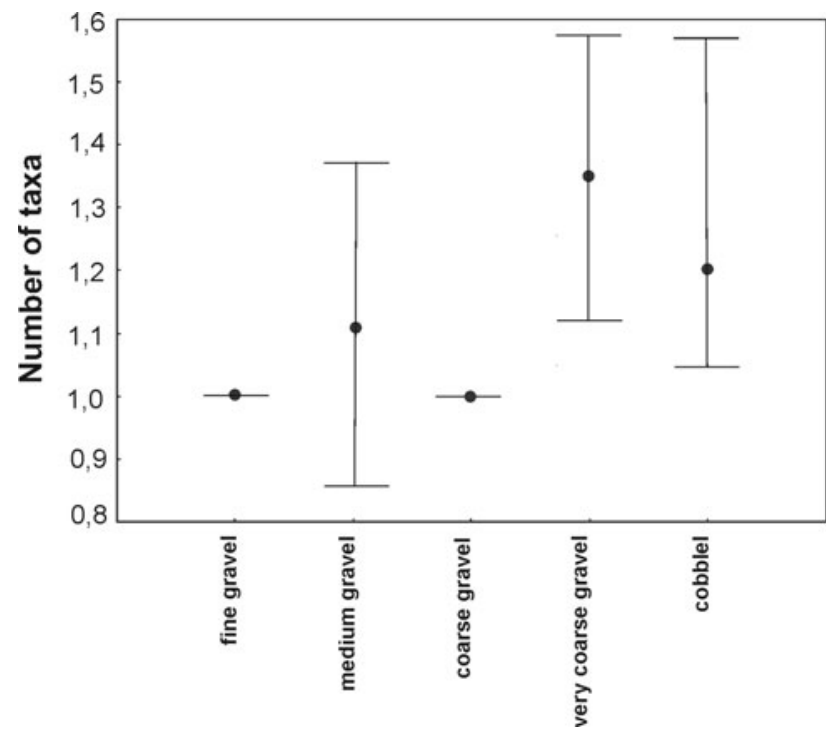

Fig. 2 Number of hydroid taxa (mean \pm 0.95 confidence intervals) on rocks in different size classes

There was no significant relationship between sample species richness and depth (Spearman's rank correlation: $R=-0.02, p>0.05$ ).

Mean number of species per sample (on colonized rocks) did not differ between classes of rock size (KruskalWallis test: $H=7.03, p>0.05$ ) (Fig. 2). However, the correlation between number of species and rock size (treated as continuous variable) was significant but low (Spearman's rank correlation: $R=0.21, p<0.05$ ). The species composition on rocks was not related to either rocks' surface area (Spearman's rank correlation: $R=$ $-0.017, p>0.05$ ) or depth (Spearman's rank correlation: $R=0.109, p<0.05)$ that was confirmed by RELATE procedure.

Stolonal species (Bougainvillia cf. superciliaris, Cuspidella procumbens) more commonly occupied smallersized rocks with the exception of Campanularia volubilis which occurred more frequently on larger rocks, while erect forms (e.g., Lafoea dumosa and Sarsia sp.) were most often recorded on coarse, very coarse gravel and cobbles.

Algae

A total of 391 specimens of algae were examined. Among 17 investigated algal species, one belonged to the division Chlorophyta, 11 to Phaeophyta and five to Rhodophyta (Table 3). Fourteen species out of 17 collected algal species and $34 \%$ of collected algal specimens were epiphitized by hydroids. Collected algal species represented three morphological types: foliose to membranous, filamentous and leathery.

Altogether 27 hydrozoan species were found on algae. The highest number of hydroid species (21) and hydroid records (209) were found on Phaeophyta, which were also
Table 3 List of collected species of macroalgae
$N_{\mathrm{T}}$-total number of collected algae, $N_{\mathrm{A}}$-number of hydroid records on algal substrate, $N_{\mathrm{AH}}$-number of algal specimens colonized by hydroids, $N_{\mathrm{sp}}-$ number of hydroid species associated

\begin{tabular}{lrrrr}
\hline Algae & $N_{\mathrm{T}}$ & $N_{\mathrm{A}}$ & $\mathrm{N}_{\mathrm{AH}}$ & $N \mathrm{sp}$ \\
\hline Chlorophyta & 2 & 2 & 2 & 1 \\
Acrosiphonia sonderi (Kützing) Kornmann, 1962 & 2 & 2 & 2 & 1 \\
Phaeophyta & 344 & 209 & 101 & 21 \\
Alaria esculenta (Linnaeus) Greville, 1830 & 155 & 53 & 33 & 15 \\
Chorda tomentosa Lyngbye, 1819 & 1 & 1 & 1 & 1 \\
Desmarestia aculeata (Linnaeus) Lamouroux, 1813 & 1 & 1 & 1 & 1 \\
Dictiosiphon foeniculaceus (Hudson) Greville, 1830 & 1 & 3 & 1 & 3 \\
Fucus distichus Linnaeus, 1765 & 1 & 2 & 1 & 2 \\
Laminaria digitata (Hudson) Lamouroux, 1813 & 62 & 50 & 21 & 15 \\
Laminaria hyperborea (Gunnerus) Foslie, 188 & 1 & 1 & 1 & 1 \\
Laminaria solidungula J. Agardh, 1868 & 19 & 8 & 5 & 7 \\
Saccharina latissima (Linnaeus) C.E. Lane, C. Mayes, Druehl & 100 & 72 & 37 & 20 \\
G.W. Saunders, 2006 & & & & \\
Saccorhiza dermatodea (De La Pylaie) J. Agardh, 1868 & 2 & 0 & 0 & 0 \\
Sphacelaria arctica Harvey, 1857 & 1 & 1 & 1 & 1 \\
Laminaria sp. & 6 & 157 & 6 & 12 \\
Rhodophyta & 27 & 54 & 26 & 18 \\
Callophyllis cristata (Agardh) Kutzing, 1849 & 2 & 2 & 2 & \\
Dumontia contorta (S.G. Gmelin) Ruprecht, 1850 & 4 & 3 & 4 & 2 \\
Odonthalia dentata (Linnaeus) Lyngbye, 1819 & 3 & 3 & 3 & 2 \\
Phycodrys rubens (Linnaeus) Batters, 1902 & 17 & 46 & 17 & 17 \\
Ptilota plumosa (Linnaeus) Agardh, 1817 & 1 & 0 & 0 & 0 \\
\hline
\end{tabular}


Fig. 3 Number of hydroid species (mean \pm 0.95 confidence intervals) on different morphological types of algae; $L$ leathery, $F$ foliose to membranous, $B$ filamentous (a) and on different algal divisions, $P$ Phaeophyta and $R$ Rhodophyta (b)
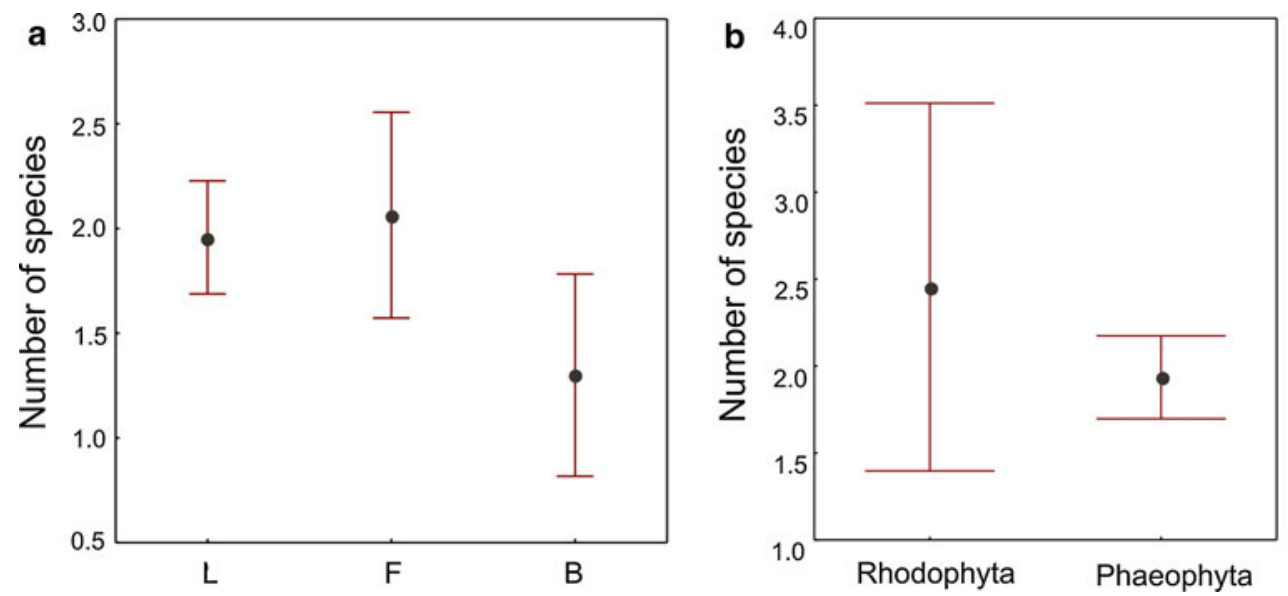

most intensively sampled (Table 3 ). Eighteen species and 54 records were noted on Rhodophyta. Chlorophyta served as substrate for hydroid settlement only twice. The only species colonizing Chlorophyta was $C$. volubilis. Frequency of hydroid occurrence was higher on Rhodophyta (96\%) comparing to Phaeophyta ( $29 \%)$.

Halecium cf. speciosum, Halecium textum, Eudendrium arbuscula, Hydractinia cf. monoon were noted exclusively on algae but were all very rare species (number of records $<3)$.

The mean sample species richness on colonized algae was 1.4 ranging from a minimum of 1 species to a maximum of 10 species per algae (maximum species richness found on $P$. rubens). No significant differences in mean sample species richness among the three morphological types of algae (foliose to membranous, filamentous and leathery) (Kruskal-Wallis test: $H=5.35$, $p>0.05$ ) (Fig. 3a) or between Phaeophyta and Rhodophyta (Kruskal-Wallis test: $H=0.22, p>0.05$ ) (Fig. 3b) were noted.
There were also no significant dissimilarities in species composition between either Rhodophyta and Phaeophyta (one-way ANOSIM: Global $R=0.032, p>0.05$ ) or among three algal morphological types (one-way ANOSIM: Global $R=0.027, p>0.05$ ). No separation of samples between different morphological forms and between Phaeophyta and Rhodophyta could be detected on the nMDS plots (Fig. 4a, b). Even if multivariate analysis did not indicate significant effects of taxonomic or morphological algal categories on hydroid species composition, some patterns of distribution of hydroid morphological forms could be observed among the dominant four algal host species. Hydroid species with erect colony form (Halecium arcticum, Halecium curvicaule and Symplectoscyphus tricuspidatus) were more common on brown algae ( $L$. digitata, S. latissima and A. esculenta), while stolonal hydroid colonies (C. volubilis, Orthopyxis integra and Calycella syringa) most frequently colonized red algae ( $P$. rubens). One exception was erect Halecium muricatum noted on $P$. rubens.
Fig. 4 nMDS plot of BrayCurtis similarities of hydroid species composition (presence/ absence data) in algal samples. Symbols represent different morphological types of algae; $L$ leathery, $F$ foliose to membranous, $B$ filamentous (a) and on different algal divisions; $P$ Phaeophyta and $R$ Rhodophyta (b)

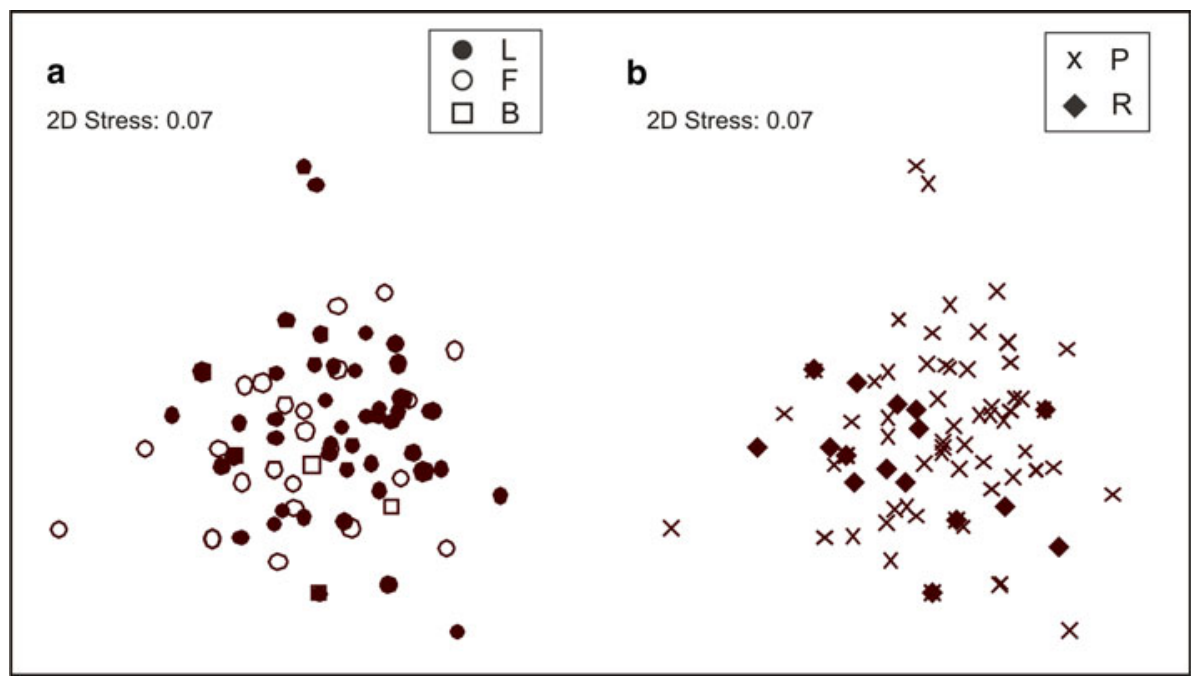


Table 4 List of bryozoan host species and their morphological forms ( $E$ erect, $E n$ encrusting) colonized by hydroids (uniques and duplicates are excluded)

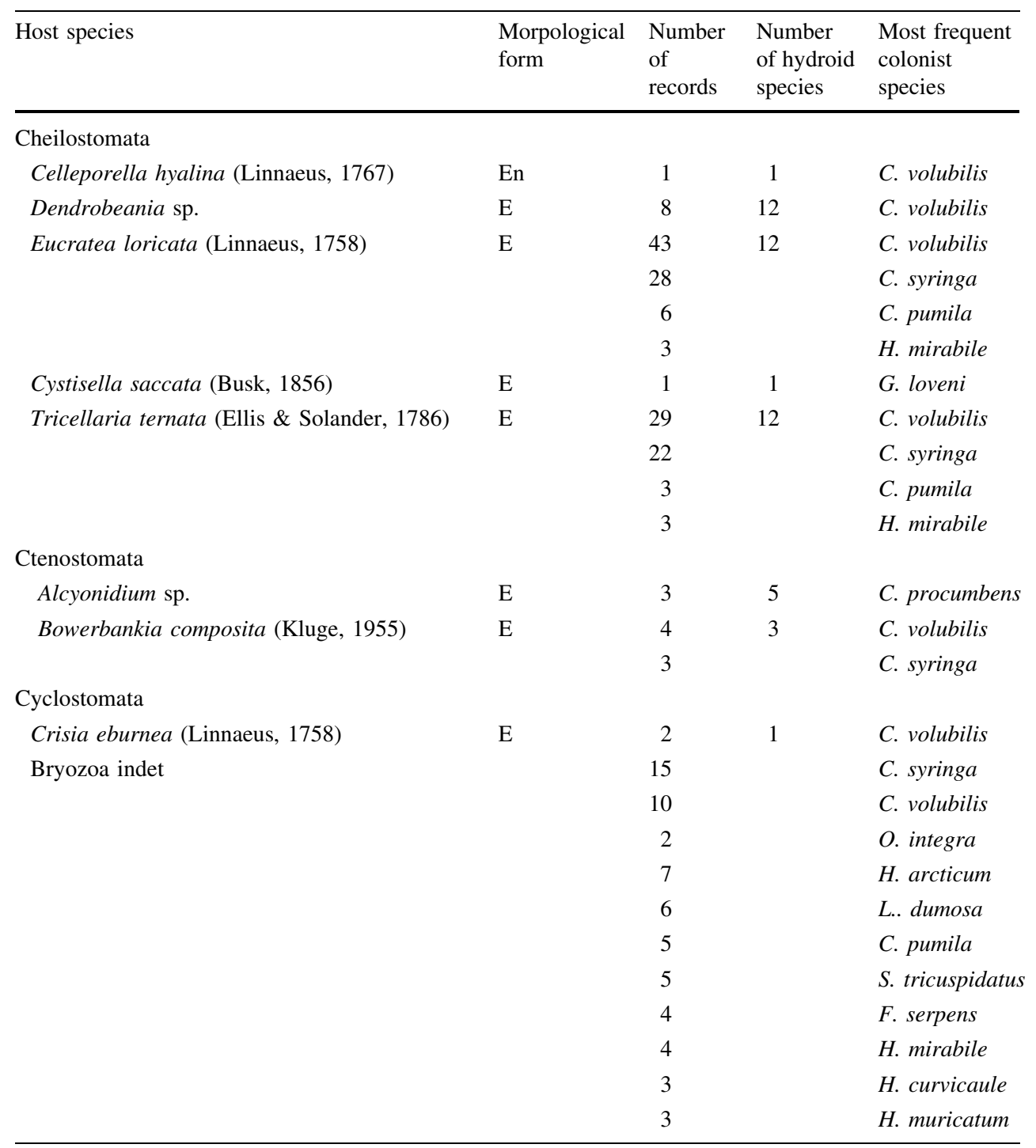

There was a significant but low dissimilarity in hydroid species composition among different bryozoan host species (one-way ANOSIM, global $R=0.095, p<0.05$ ).

Hydroids as substrate

Fifteen hydroid species served as a substrate for 16 hydroid colonists (Table 5). The highest total number of hydroid colonists' species was found on $S$. tricuspidatus (8 species). The highest sample species richness was recorded on specimens of Obelia longissima (5 species), Sertularella polyzonias and $S$. tricuspidatus (each 4 species). Among the most frequent $(F>10 \%)$ species colonizing other hydroids were $C$. volubilis (36\%), C. syringa $(28 \%)$ and O. integra $(13 \%)$. There were significant but low differences in hydroid colonists' composition among different hydroid substrate species (one-way ANOSIM: Global $R=0.152, p<0.05$ ). 
Table 5 The list of hydroid substrate and hydroid colonists and their morphological forms ( $E$ erect, $S$ stolonal): N sp. allnumber of all specimens examined in the present study, $\mathrm{N}$ sp. col.—number of specimens that were colonized by other hydroids

\begin{tabular}{|c|c|c|c|c|c|}
\hline Substrate & $\begin{array}{l}\text { Morphological } \\
\text { form of substrate }\end{array}$ & $\begin{array}{l}\mathrm{N} \text { sp. } \\
\text { all }\end{array}$ & $\begin{array}{l}\text { N sp. } \\
\text { col. }\end{array}$ & $\begin{array}{l}\text { Most frequent } \\
\text { colonist species }\end{array}$ & $\begin{array}{l}\text { Morphological form } \\
\text { of colonist species }\end{array}$ \\
\hline \multicolumn{6}{|l|}{ Anthoathecata } \\
\hline E. cf. capillare & $\mathrm{E}$ & 5 & 1 & B. cf. superciliaris & $\mathrm{S}$ \\
\hline \multirow[t]{3}{*}{ E. annulatum } & $\mathrm{E}$ & 29 & 3 & C. volubilis & $\mathrm{S}$ \\
\hline & & & & C. syringa & $\mathrm{S}$ \\
\hline & & & & H. arcticum & $\mathrm{E}$ \\
\hline \multicolumn{6}{|l|}{ Leptothecata } \\
\hline F. serpens & $\mathrm{S}$ & 19 & 1 & C. volubilis & $\mathrm{S}$ \\
\hline \multirow[t]{2}{*}{ G. loveni } & $\mathrm{E}$ & 49 & 4 & S. plicatile & $\mathrm{E}$ \\
\hline & & & & E. sp. & $\mathrm{E}$ \\
\hline \multirow[t]{3}{*}{ H. arcticum } & $\mathrm{E}$ & 78 & 4 & $R$. roseum & $\mathrm{S}$ \\
\hline & & & & C. syringa & $\mathrm{S}$ \\
\hline & & & & C. procumbens & $\mathrm{S}$ \\
\hline \multirow[t]{5}{*}{ H. muricatum } & $\mathrm{E}$ & 28 & 5 & C. volubilis & $\mathrm{S}$ \\
\hline & & & & O. integra & $\mathrm{S}$ \\
\hline & & & & C. syringa & $\mathrm{S}$ \\
\hline & & & & L. dumosa & $\mathrm{E}$ \\
\hline & & & & S. tricuspidatus & $\mathrm{E}$ \\
\hline \multirow[t]{2}{*}{ H. textum } & $\mathrm{E}$ & 8 & 2 & C. syringa & $\mathrm{S}$ \\
\hline & & & & C. procumbens & $\mathrm{S}$ \\
\hline \multirow[t]{3}{*}{ L. dumosa } & $\mathrm{E}$ & 107 & 3 & C. volubilis & $\mathrm{S}$ \\
\hline & & & & O. integra & $\mathrm{S}$ \\
\hline & & & & O. longissima & $\mathrm{E}$ \\
\hline L. maxima & $\mathrm{E}$ & 16 & 1 & G. loveni & $\mathrm{E}$ \\
\hline \multirow[t]{5}{*}{ O. longissima } & $\mathrm{E}$ & 15 & 5 & B. cf. superciliaris & $\mathrm{S}$ \\
\hline & & & & C. syringa & $\mathrm{S}$ \\
\hline & & & & Coryne sp. & $\mathrm{S}$ \\
\hline & & & & O. integra & $\mathrm{S}$ \\
\hline & & & & H. serrata & $\mathrm{S}$ \\
\hline R. verticillatus & $\mathrm{E}$ & 10 & 1 & L. dumosa & $\mathrm{E}$ \\
\hline S. cupressoides & $\mathrm{E}$ & 18 & 3 & C. volubilis & $\mathrm{S}$ \\
\hline \multirow[t]{2}{*}{ S. rugosa } & $\mathrm{E}$ & 27 & 2 & H. mirabile & $\mathrm{S}$ \\
\hline & & & & S. tenella & $\mathrm{E}$ \\
\hline \multirow[t]{2}{*}{ S. tricuspidatus } & $\mathrm{E}$ & 146 & 19 & C. volubilis & $\mathrm{S}$ \\
\hline & & & 4 & C. syringa & $\mathrm{S}$ \\
\hline
\end{tabular}

Hydroids predominantly occupied hydroids of the order Leptothecata (Fig. 5). Species of the family Sertulariidae were most often colonized by other hydroids both in case of number of species (4 species of Sertulariidae, which made up $27 \%$ of all hydroid substrates) (Fig. 5a) and number of records (48\%) (Fig. 5b). Regarding antoathecates, merely two species of the family Eudendriidae provided a substrate for colonizing hydroids.

Hydroid species living on other hydroids belonged to nine families (Fig. 6). Species of the order Anthoathecata were in the minority comparing to Leptothecata. Campanulariidae were observed attached to other hydroids with the highest number of records (41\%) (Fig. 6b) and with the highest richness (4 species which made up $23 \%$ of all hydroid colonist species) (Fig. 6a).

\section{Discussion}

The most common substrates colonized by hydroids in the study area include rocks, macroalgae, bryozoans and other hydrozoans. Despite the fact that some hydroid species were observed attached to only one type of substrate, we cannot draw conclusions about substrate specificity. These species were particularly rare in the study area; thus, more material is needed to confirm their substrate preferences. 
Fig. 5 Distribution of hydroid substrate among different families in terms of number of species (a), number of hydroid records as hydroid host (b)
Fig. 6 Distribution of colonists among different families in terms of species number (a), number of records (b)
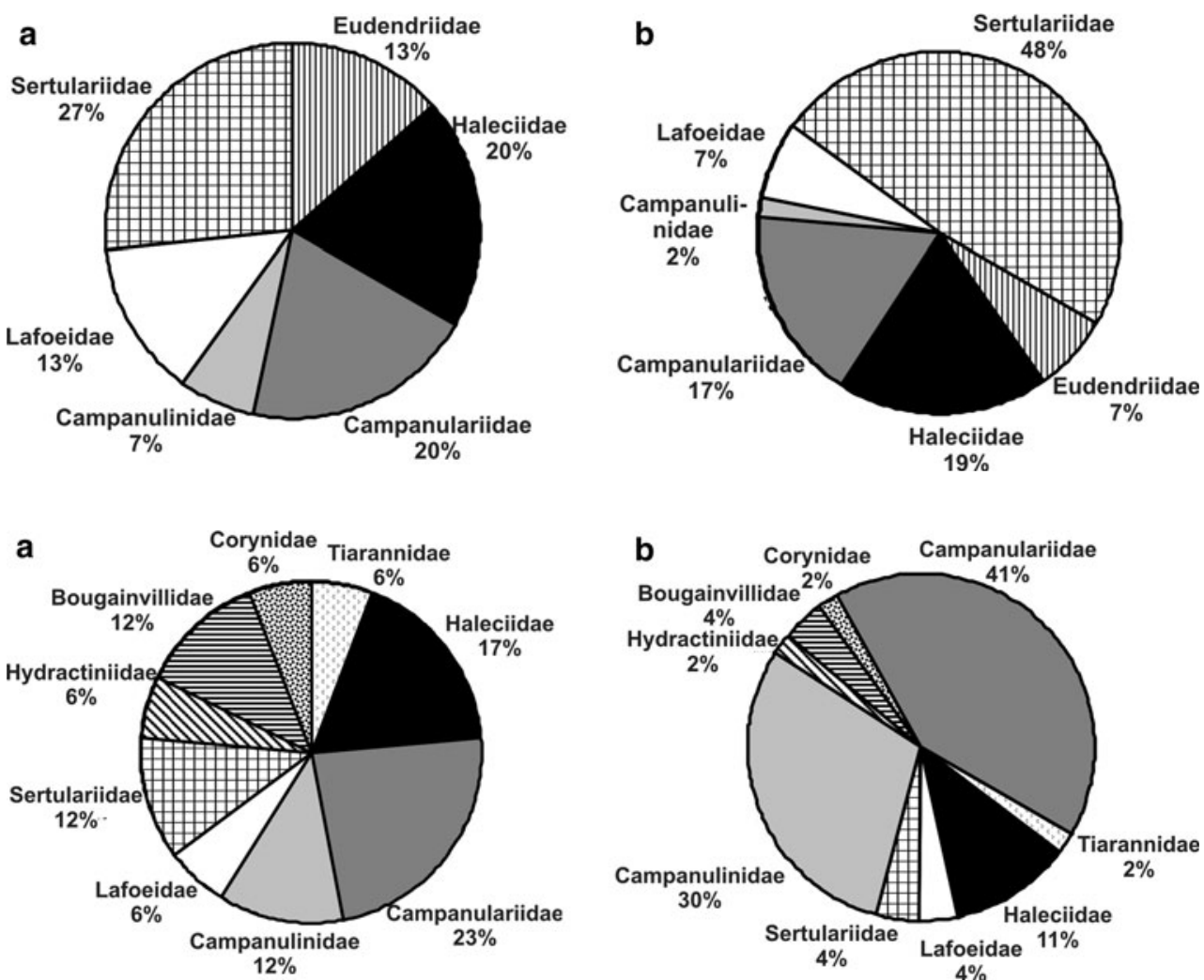

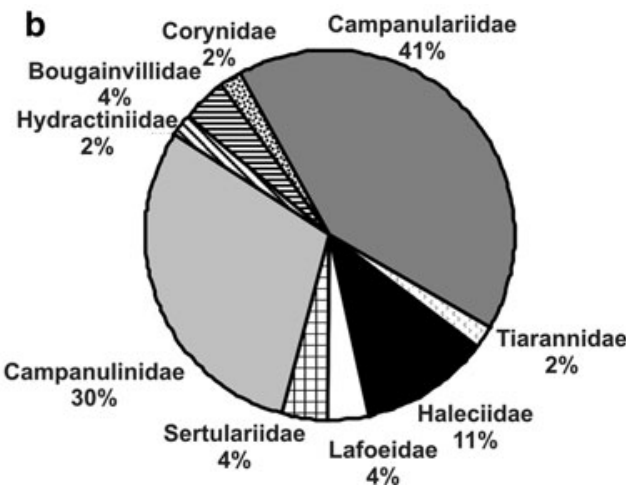

Rocks

As pioneer organisms, hydroids are present even on the smallest rocks that are prone to frequent mechanical disturbances. The surface of the smallest rock colonized by hydroid (B. cf. superciliaris) was $0.5 \mathrm{~cm}^{2}$. No distinct correlation between species richness and rock size was observed in the present study. However, hydroids occurred more often on rocks of larger size. A marked trend of increasing numbers of species with increasing rock surface is observed for lithophyllic bryozoan communities in the Arctic and Antarctic waters (Barnes et al. 1996; Kukliński et al. 2006). Such patterns are explained by the higher frequency of disturbance caused by wave forces affecting smaller rocks (rolling over and overturning by storms and currents) (Osman 1977). Small rocks are regularly subjected to mechanical scratching, which means the associated biota is only maintained in the early stages of succession. Conversely, the larger rocks remain stable and undisturbed for longer time, and thus, the succession stage of the assemblages is likely to be more advanced. According to the intermediate disturbance hypothesis, (Connell 1978) local species diversity is maximized when ecological disturbance is neither too rare nor too frequent. The largest rocks and boulders that do not turn over do not necessarily support the highest diversity. Owing to the absence of disturbance, species number falls as a result of competitive elimination of inferior competitors by one or a few dominant species (Osman 1977). Medium-sized rocks should have the highest diversity as they are old enough to accumulate number of species and become disturbed before dominance can occur (Osman 1977).

Factors related to depth are significant in determining hydroid occurrence and species richness on rocky substrates. Although the disturbing impact of many physical factors decreases with depth (e.g., wave action, strong currents, iceberg scouring), rocks occurring in shallow waters are colonized by hydroids more frequently, and hydroid species richness is slightly higher on rocks in shallow waters. The shallow water zone (0-40 m depth) is more diverse in terms of habitat availability, especially in the Arctic. In the deeper part of fjords and continental shelf around Svalbrd, the soft homogenous bottom predominates. Shallow waters are also more favorable for suspension-feeding organisms because of better food availability and water flow conditions (Faucci and Boero 2000).

The hydroid species composition on rocky substrates is relatively homogenous and generally not related to rock surface area or sampling depth. However, some patterns of distribution among the most common species are noted. Stolonal B. cf. superciliaris, C. volubilis and C. procumbens are found more often on small rocks. Species with erect growth (e.g., L. dumosa and Sarsia sp.) forms are more common on larger, stable substrates. This tendency 
concurs with Bishop's concept of spatial refuge (Bishop 1989). This author contends that peripheral habitats, often small and ephemeral and/or associated with unstable conditions (e.g., small rocks), can provide refuge from competition and can be favorable for poor space competitors.

\section{Algae}

The total number of hydroid species recorded is comparable on Phaeophyta (21 species) and Rhodophyta (18 species). Single species was noted on Chlorophyta. The differences, however, in sample species richness and species composition between red and brown algae are not significant (green algae was excluded from the statistical analysis because of the small number of records). Very similar results were obtained in the study of macrofauna associated with macroalgae in Spitsbergen fjord (Kongsfjorden). The same number of hydroid species was noted on red and brown algae, while there were none on green algae (Lippert et al. 2001). Different trends of hydroid preference for algal substrates are reported from various regions. A tendency for hydroids to favor algae from the Phaeophyta division over Rhodophyta and Chlorophyta is observed near Asamushi, Japan (Nishihira 1965, 1966), and in the mangrove ecosystem at Twin Cays, Belize (Calder 1991). Shepherd and Watson (1970) and Genzano and Rodriguez (1998) report opposite hydroid preferences with Rhodophyta favored over Phaeophyta in south Australia and the coastal waters of Argentina, respectively.

The selection of particular algae by larvae depends on many factors. Green algae are scarcely ever inhabited by epifauna. Nishihira (1965) designated some characteristic features of Chlorophyta, such as their morphological appearance, short life span, and position in the mid-littoral zone, as being disadvantageous for epifaunal settlement. Epibiont larval preferences for specific algal groups might be driven by inhibiting or attracting mechanisms connected with secretions produced by algal tissues (Nishihira 1968; Shepherd and Watson 1970; Oswald and Seed 1986). Larval settlement might be deterred by tannic substances secreted by many brown algae or the mucus excreted by some brown and red algal tissues (Shepherd and Watson 1970). Conversely, positive chemotaxis induced by some fucoid exudates attracts the larvae of the athecate hydroid Coryne uchidai Stechow 1931 to inhabit Sargassum sp. (Nishihira 1968).

Despite pronounced variation in the morphology of algal substrates (foliose to membranous, filamentous or leathery), there are no significant differences in associated hydroid diversity or composition. In study of the fauna associated with macroalgae in Kongsfjorden, Lippert et al. (2001) demonstrated that faunal composition was unrelated to the morphological form of algae. Nishihira $(1966,1967$,
1968) stated that the physical appearance of the algal thallus (shape, texture, rugosity, hardiness) played an important role in the selection of algae by hydrozoan larvae. In the present material, the effect of thallus morphology on the composition of hydroid epiphytes is only detected when differences in the frequency of occurrence of the most common colonist species are compared. Stolonal $C$. volubilis was the only species that occasionally colonized filamentous, delicate algae like A. sonderi, $C$. tomentosa or D. contorta. The lack of sedentary animals on narrow filamentous thalli is a consequence of their smaller diameter size when compared to the size of hydrozoan larvae and stolons (Nishihira 1967). The thick growth of "hairs" on C. tomentosa prevents epiphytes from attaching to them. Some species that form erect colonies $(H$. arcticum, $H$. curvicaule, S. tricuspidatus) are the most common on the rhizoids of brown algae (L. digitata, S. latissima and A. esculenta). The rhizoids of these kelp species are highly structured, three-dimensional substrates with a number of crevices in the center. Some hydrozoan larvae display positive rugotaxis. They select rugose surfaces, crevices and depressions along the thalli as their attachment sites (Nishihira 1967; Shepherd and Watson 1970). Large colonies of erect forms are probably more adapted to live on stable substrates provided by kelp holdfasts. Smaller colonies of stolonal $C$. volubilis, O. integra and $C$. syringa most frequently colonized the fronds of foliose P. rubens, which offer much more delicate and flexible surface.

\section{Bryozoa}

Bryozoans are an important substrate source for hydroid settlement. About one-third of all hydroid records and $40 \%$ (23 species) of hydroid species are noted on this type of substrate. Bryozoans have often been noted as a substrate colonized by hydroids (e.g., Genzano and Rodriguez 1998; Genzano and Zamponi 2003; Henry et al. 2008; Genzano et al. 2009); however, no detailed descriptions (such as bryozoan host taxonomic composition) on the epizoic type of associations between hydrozoans and bryozoans are included in these studies. Piraino et al. (1992) described the parasitic relationship between the hydroid Halocoryne epizoica Hadzi, 1917, and the bryozoan Schizobrachiella sanguinea (Norman 1868), in which the hydroid lived in obligate association and feeds on the lophophoral tentacles of its bryozoan host. Osman and Haugsness (1981) reported a mutualistic relationship between the hydroid Zanclea sp. and the bryozoans Schizoporella errata (Waters 1878) and Celleporaria brunnea (Hincks 1884). Colonies of both associates were highly integrated, with the skeletons of the bryozoan covering the hydroid hydrorhiza, and both partners take advantage of increased survival and competitive ability. 
In the current study, the hydroids most often settle on bryozoans of the order Cheilostomata. This is certainly linked to bryozoan distribution patterns in Svalbard waters. Kukliński (2004) reported that species representing the order Cheilostomata constituted about $80 \%$ of the taxa occurring in Spitsbergen coastal waters. However, the hydroid preference to colonize Cheilostomata bryozoans can also result from morphological characteristics of species representing this order. Many species of Cheilostomata are larger in size and have complex, erect form what is in opposite to majority of Ctenostomata and Cyclostomata, which are mostly characterized by small size and encrusting colony type (Kukliński, unpublished observation). In the present study, almost all host species are of erect colony forms. Large bryozoan colonies are supposed to be a favorable substrate for suspension-feeding colonists since upright shoots can raise the hydroids into the water column where better water flow and food conditions are coupled with protection from burial by mineral particles. They also provide fast growing, three-dimensional structures beneficial for early colonists. Bryozoans are one of the stronger space competitors in the Arctic that yield only to ascidians and demosponges during encounters, but they are more common (Barnes and Kukliński 2004). The strategy of colonizing the surface of winners instead of competing with them for primary space can be an efficient strategy for relatively weak hydrozoan competitors (Orlov 1997). This strategy is employed by variety of other macroinvertebrates. Many bryozoans are obligate epiphytes that take advantage of competitor-free algal substratum (Seed and O’Connor 1981; Bishop 1989). Upright sessile epifauna serves as shelter and nursery ground for juvenile scallops (Bradshaw et al. 2003).

Hydroids as substrate

Few studies focus on the phenomenon of either vagile or sessile epizoism on hydroids (Millard 1973; Hughes 1975; Orlov 1997; Bavestrello et al. 1996). Hydroid-hydroid associations are most often noted only briefly in taxonomic and/or ecological studies (e.g., Schuchert 2001; Genzano and Rodriguez 1998; Zamponi et al. 1998; Henry et al. 2008; Genzano et al. 2009). Large colonies of hydroids are known to offer refuge and food supply for deposit feeders and carnivores (Hughes 1975). As substrates, hydroids can increase both the diversity and the abundance of benthic fauna in coastal waters (Bradshaw et al. 2003), and they constitute the major substrate for epizoic hydrozoan fauna, for example, on the Argentinian continental shelf (Genzano and Zamponi 2003). The advantage of colonizing asexually reproducing substrates such as Hydrozoa is the unlimited and permanent growth of new hydrocauli (i.e., the new substrate) and the better access to seston they provide to suspension-feeding animals. A continuously growing substrate can be colonized quickly by epizoic hydroids from neighboring hydrocauli through stoloniferous growth (Genzano et al. 2009). Orlov (1997) examined the hydroidhydroid associations closely and identified the morphological plasticity of colonists as an adaptation of hydroids to an epizoic mode of life. In a study of multilevel epizoic hydroid complexes, Orlov (1997) observed that the colony structure of some species established on other hydroids differed substantially from those described for other substrates. The size of the host hydranths and epizoic hydrozoan colonies differed, with the latter usually being smaller (Orlov 1997). Such differentiation can reduce competition between the epibiont and the host for food items of the same size.

Hydrozoan colonies are an important substrate for hydroid colonization. As many as 15 species of hydroids (26\% of all the species recorded in this study area) support other associated hydroid species ( 18 species). About $6 \%$ of all the hydroid records are noted on other hydroids. The host species belong mainly to the order Lepthothecata and the family Sertulariidae. Hydroid colonies that carry other organisms must be quite large and stiff enough to resist additional ballast. The study material includes hydroid specimens colonized by a number of other species; these include those of a large colony size such as $O$. longissima (colonized by five epizoic hydroids) and rigid forms like S. polyzonias and S. tricuspidatus (each hosting four epizoic species). In contrast, hydroid colonists are mostly characterized by stolonal morphology forms and/or minute sizes. The most common hydroid colonists belong to the families Campanulariidae $(41 \%)$ and Campanulinidae (30\%). The majority of Campanulariidae records (C. volubilis and $O$. integra) and all Campanulinidae consist of stolonal species. Only two records of erect Campanulariidae (G. loveni and O. longissima) are noted on other hydroids; however, these colonies did not reach a substantial size (Ronowicz, personal observation).

\section{Conclusions}

This study provides information about the effect of substrate characteristics on hydroid epibionthic communities in Svalbard region. Hydroids are successful pioneer organisms that can rapidly colonize available rocky, algal or animal surfaces. The opportunistic nature of hydroids is reflected in the lack of substrate specificity of hydroid species and in the fact that the species composition is similar regardless of substrate type. Also, substrate characteristics such as rock surface area, morphological types of algae and different divisions of algal host do not have a large influence on hydroid species composition. The presence of hydroids is related to the surface area of rocky 
substrate. Significant but low dissimilarities characterized hydroid assemblages dwelling on different hydrozoan and bryozoan hosts. Erect colonies of bryozoans and hydroids constitute important substrates for hydroid settlement (mainly stolonal forms). Colonization of the available upright surface (algae, erect bryozoans or hydroids) is a strategy that enables to settle on indeterminately growing substrate that provides a spatial refuges from highly competitive primary space.

Acknowledgments Thank you to Agnieszka Tatarek for helping with algal specimens identification. We are grateful to Peter Schuchert (Museum of Natural History, Geneva) for taxonomical consultation of problematic material. The study was completed thanks to the funding provided by the Polish Ministry of Science and Higher Education (Grant number N N304 071934) and National Science Center (E12AP004).

Open Access This article is distributed under the terms of the Creative Commons Attribution License which permits any use, distribution, and reproduction in any medium, provided the original author(s) and the source are credited.

\section{References}

Barnes DKA, Kuklińki P (2004) Scale-dependent variation in competitive ability among encrusting Arctic species. Mar Ecol Prog Ser 275:21-32

Barnes DKA, Rothery PJ, Clarke A (1996) Colonisation and development in encrusting communities from the Antarctic intertidal and sublittoral. J Exp Mar Biol Ecol 196:251-265

Bavestrello G, Cerrano R, Cattaneo-Vietti R, Sarà M (1996) Relationships between Eudendrium glomeratum (Cnidaria, Hydromedusae) and its associated vagile fauna. Scientia Marina 60(1):137-143

Bishop JDD (1989) Colony form and the exploitation of spatial refuges by encrusting bryozoa. Biol Rev 64:197-218

Boero F (1984) The ecology of marine hydroids and effects of environmental factors: a review. Mar Ecol 5:93-118

Boero F, Hewitt CL (1992) A hydrozoan, Zanclella bryozoophila ngen, nsp (Zanleidae), symbiotic with a bryozoan, with a discussion of the Zancleoidea. Can J Zool 70:1645-1651

Bradshaw C, Collins P, Brand AR (2003) To what extent does upright sessile epifauna affect benthic biodiversity and community composition? Mar Biol 143:783-791

Calder DR (1991) Associations between hydroid species assemblages and substrate types in the mangal at Twin Cays, Belize. Can J Zool 69:2067-2074

Cerrano C, Puce S, Chantore M, Bavestrelo G, Cattaneo-Vietti R (2001) The influence of the epizoic hydroid Hydractinia angusta on the recruitment of the Antarctic scallop Adamussium colbecki. Polar Biol 24:577-581

Clarke KR, Warwick RM (2001) Change in marine communities: an approach to statistical analysis and interpretation, 2nd edn. Plymouth Marine Laboratory, Plymouth

Coma R, Llobet I, Zabala M, Gili JM, Hughes RG (1992) The population dynamics of Halecium petrosum and Halecium pussilum (Hydrozoa, Cnidaria), epiphytes of Halimeda tuna in the northwestern Mediterranean. Sci Mar 56(2-3):161-169

Connell JH (1978) Diversity in tropical rain forest and coral reefs. Science 199:1302-1310
Dean TA, Hurd LE (1980) Development in an estuarine fouling community: the influence of early colonists on later arrivals. Oecologia 46:295-301

Faucci A, Boero F (2000) Structure of an epiphytic hydroid community on Cystoseira at two sites of different wave exposure. Sci Mar 64:255-264

Genzano NG, Rodriguez GM (1998) Association between hydroid species and their substrates from the intertidal zone of Mar del Plata (Argentina). Miscellania Zoologia 21(1):21-29

Genzano NG, Zamponi MO (2003) Hydroid assemblages from Mar del Plata, Argentina, at depths between 0 and $500 \mathrm{~m}$. Distribution and biological substrata. Oceanol Acta 25:303-313

Genzano GN, Giberto D, Schejter L, Bremec C, Meretta P (2009) Hydroid assemblages from the Southwestern Atlantic Ocean (34-42 ${ }^{\circ}$ S). Mar Ecol 30:33-46

Gili JM, Hughes RG (1995) The ecology of marine benthic hydroids. Oceanogr Mar Biol Annu Rev 33:351-426

Gulliksen B, Svensen E (2004) Svalbard and life in polar oceans. Kom Forlag, Kristiansund

Henry L-A, Nizinski MS, Ross SW (2008) Occurrence and biogeography of hydroids (Cnidaria: Hydrozoa) from deep-water coral habitats off the southeastern United States. Deep-Sea Res I $55: 788-800$

Hughes RG (1975) The distribution of epizoites on the hydroid Nemertesia antennina (L) (Hydrozoa: Plumulariidae). J Mar Biol Assoc UK 55:275-294

Hughes RG, Johnson S, Smith ID (1991) The growth patterns of some hydroids that are obligate epiphytes of seagrass leaves. Hydrobiologia 216(217):205-210

Kukliński P (2004) Ecology of bryozoans from Svalbard waters. Dissertation, Institute of Oceanology, Polish Academy of Sciences, Poland

Kukliński P, Gulliksen B, Lønne OJ, Węsławski JM (2005) Composition of bryozoan assemblages related to depth in Svalbard fjords and sounds. Polar Biol 28:619-630

Kukliński P, Gulliksen B, Lønne OJ, Węsławski JM (2006) Substratum as a structuring influence on assemblages of Arctic bryozoans. Polar Biol 29:652-661

Lippert H, Iken K, Rachor E, Wiencke C (2001) Macrofauna associated with macroalgae in the Kongsfjord (Spitsbergen). Polar Biol 24:512-522

Loeng H (1991) Features of the physical oceanographic conditions of the Barents Sea. In: Sakshaug E et al (eds) Proceedings of the pro mare symposium on the polar marine ecology, Trondheim, 12-16 May 1990, Polar Res 10:5-18

Millard NAH (1973) Autoepizoism in South African hydroids. Publ Seto Mar Biol Lab 20:23-24

Naumov DV (1969) Hydroids and hydromedusae of the USRR. Israel Program for Scientific Translation, Jerusalem

Nishihira M (1965) The association between Hydrozoa and their attachment substrata with special reference to algal substrata. Bull Mar Biol Stat Asamushi 12:75-92

Nishihira M (1966) Ecological distribution of epiphytic Hydrozoa on the Tsuchiya coast near the Marine Biological Station of Asamushi. Bull Mar Biol Stat Asamushi 12(4):179-205

Nishihira M (1967) Observations on the selection of algal substrata by hydrozoan larvae, Sertularella miurensis in nature. Bull Mar Biol Stat Asamushi 12:35-48

Nishihira M (1968) Experiments on the algal selection by the larvae of Coryne uchidai Stechow (Hydrozoa). Bull Mar Biol Stat Asamushi 13:83-89

Orlov D (1997) Epizoic associations among the White Sea hydroids. Sci Mar 61(1):17-26

Osman RW (1977) The establishment and development of a marine epifaunal community. Ecol Monogr 47:37-63 
Osman RW, Haugsness JA (1981) Mutualism among sessile invertebrates: a mediator of competition and predation. Science $21: 846-848$

Oswald RC, Seed R (1986) Organisation and seasonal progression within the epifaunal communities of coastal macroalgae. Cah Biol Mar 27:29-40

Piraino S, Bouillon J, Boero F (1992) Halocoryne epizoica (Cnidaria, Hydrozoa), a hydroid that 'bites'. In: Bouillon J et al (eds) Aspects of hydrozoan biology, Sci Mar 56(2-3):141-147

Puce S, Cerrano C, Di Camillo CG, Bavestrello G (2008) Hydroidomedusae (Cnidaria: Hydrozoa) symbiotic radiation. J Mar Biol Assoc UK 88:1713-1719

Ronowicz M, Włodarska-Kowalczuk M, Kukliński P (2008) Factors influencing hydroids (Cnidaria: Hydrozoa) biodiversity and distribution in Arctic kelp forest. J Mar Biol Assoc UK 88:1567-1575

Ronowicz M, Włodarska-Kowalczuk M, Kukliński P (2013) Depthand substrate-related patterns of species richness and distribution of hydroids (Cnidaria, Hydrozoa) in Arctic coastal waters (Svalbard). Mar Ecol 34(Suppl 1). doi:10.1111/maec.12034

Ryland JS (1963) Systematic and biological studies on Polyzoa (Bryozoa) from Western Norway. Sarsia 14:1-61

Schuchert P (2001) Hydroids of Greenland and Iceland (Cnidaria, Hydrozoa). Medd Grønland 53:1-184
Seed R, O'Connor RJ (1981) Community organization in marine algal epifaunas. Annu Rev Ecol Syst 12:49-74

Shepherd SA, Watson JE (1970) The sublittoral ecology of West Island, South Australia: 2. The association between hydroids and algal substrate. Trans R Soc South Aust 94:139-146

Sutherland JP (1981) The fouling community at Beaufort, North Carolina: a study in stability. Am Nat 118(4):499-519

Sutherland JP, Karlson RH (1977) Development and stability of the fouling community at Beaufort, North Carolina. Ecol Monogr 47(4):425-446

Svendsen H, Beszczynska-Møller A, Hagen JO et al (2002) The physical environment of Kongsfjorden-Krossfjorden, an Arctic fjord system in Svalbard. Polar Res 21:133-166

Voronkov A, Stepanjants SD, Hop H (2010) Hydrozoan diversity on hard bottom in Kongsfjorden, Svalbard. J Mar Biol Assoc UK 90:1337-1352

Watson JE (1992) The hydroid community of Amphibolis seagrasses in south-eastern and south-western Australia. Sci Mar 56: $217-227$

Wentworth CK (1922) A scale of grade and class terms for clastic sediments. J Geol 30:377-392

Zamponi MO, Genzano GN, Acuňa FH, Excoffon AC (1998) Studies of benthic cnidarian taxocenes along a transect off Mar del Plata (Argentina). Russ J Mar Biol 24(1):7-13 